\title{
CHALDON FACES
}

\section{David Garnett}

(From Familiar Faces, Chatto \& Windus, 1962)

Tommy [Stephen Tomlin] left London to go and live and work alone in a Dorsetshire village called East Chaldon, or Chaldon Herring, where he had taken the end cottage in a 'Terrace' of three or four labourers' dwellings. A few weeks later he invited me down for a weekend. He met me at Wool and we walked together for several miles over 'Egdon Heath' - as Hardy called it - before we reached Chaldon and his scantily furnished habitation. We talked about Blake, both of us speculating on whether a key might be found to unlock the Prophetic Books: the difficuly being that by their nature they attracted interpreters who had even more bees in their bonnets than Blake himself.

The cottage was cold, for it was winter and there was no proper fire. We ate bread and cheese and drank beer and tea and then, when I was thinking of bed, Tommy said that he had promised the lady who rented the vicarage to go round to coffee. Would I mind coming? And would I mind very much if he put on a dinner jacket?

While he changed, I brushed my hair and scrubbed my nails. In the vicarage we were greeted by a riot of Scotties and Mrs Ashburnam welcomed us. She was a pleasant, colourless lady and all I remember of her is the happiness which our arrival aroused. She had very nearly given us up - for Tommy was an hour or so late - but suddenly the empty day was for her transformed. She saw herself as an aristocrat, elderly and living in retirement it is true, but sought out by a brilliant young man, with impeccable antecedents. The dinner jacket, 
though somewhat crumpled, was a tribute which restored her self-respect, and banished the boredom of many empty weeks. After a little while conversation turned on Mrs Ashhurnam's nearest neighbour, Mr Powys, who I gathered was the great character of the village: a recluse, a philosopher, a deep thinker, a writer and very poor.

All this sounded familiar enough: Chaldon Herring, like The Cearne had, I gathered, its 'Dostoevsky Corner'.

Next morning Tommy took me round to call on the local philosopher. Theodore Powys lived in a hideous red-brick box with ugly windows called Beth-car. It was the only eyesore in the lovely collection of long low white-washed cottages buried in deep thatch which formed the village, but it was fortunately out of sight, fronting the bare downs. Inside its rickety gate was a space filled with long tussocky couch grass with a few dwindling fruit trees and a disused run for some fowls or ducks. There was no garden worthy of the name.

Violet Powys came to the door. She was still young, though her sons were old enough to be away at Sherborne School; she was shy, with fresh cheeks, dark eyes and hair, holding her head a little on one side. When she spoke I could tell that she was a Dorset girl, but there was something reserved and hidden about her, something not usually found in village women. Yet she could be very downright in her criticisms, but at that moment she was wary on seeing a stranger, though already she had been won by Tommy's charm and warmth. A moment later we were greeted by her husband. Theodore Powys was a grey-haired, elderly, heavily-built man with a big head and powerful rugged features. His very sharp eyes under bushy eyebrows summed one up; he was a moralist and a shrewd critic of men. The grey eyes were those of a relentless and severe judge. But the first impression was of a manner which contrasted with his rugged features and severe eyes, for he was exaggeratedly polite and spoke with an excessive humility and gentleness, as though he were an unarmed man addressing gunmen ready to shoot on sight. That was indeed how he looked upon visitors from the outside world. 
...Tommy more than repaid me for introducing him to my Bloomsbury friends. A few months after my first visit to Chaldon, he introduced me to Sylvia Townsend Warner. She was the daughter of a Harrow master and she and Tommy had made friends when he was a small boy at school. Sylvia is dark, lean and eager with rather frizzy hair. She wears spectacles and her face is constantly lighting up with amusement and intelligence and the desire to interrupt what I am saying and to cap it with something much wittier of her own. I sometimes speak slowly, waiting for the right word to come to me and when I am talking to Sylvia it very rarely does come, for she cannot restrain herself from snatching my uncompleted sentence out of my mouth and giving it a much better ending. She quivers with eagerness as though I were really going to say something good and then dashes in and transforms my sentence and my meaning into a brilliance that I should have been the last person to have thought of. In her company I soon come to think I am witty, though vicariously witty, it is true.

The first time that we met, Sylvia spoke of the beauty of the Essex marshes and I suggested that we should visit them together on the following Sunday. It was a grey wintry morning and we spent most of it in the unwarmed carriage of a very slow train and later splashing through the mud while I listened, and Sylvia gave an extraordinary display of verbal fireworks. Ideas, epigrams and paradoxes raced through her mind and poured from her mouth as though she were delirious. Meanwhile we plodded under a grey sky across grey fields towards an invisible grey horizon. Finally we reached a bank of zostera and mud and the limits of the Thames estuary at high tide. Sylvia was right, the grey marshes had a melancholy eerie beauty that was all their own. But by late afternoon when we had climbed in the dark into another empty, badly lit railway carriage and were being trundled half-frozen from Nowhere back to London, Sylvia was silent and exhausted. Brilliance and shyness were alike forgotten, our hearts were warm to one another and have remained so ever since. That long day's tramp through the mud had been immensely worth while.

And when she gave me her poems to read (I sent them on 
immediately to Charles Prentice to publish), I found it was not the sparkling epigrammist of the morning who had written them, but the quiet intimate companion who sat beside me in the cold train with her clothes and even her face spattered with mud from the Dengie Flats.

Sylvia's love and friendship remained precious to me and all the more because some time after I got to know her she became also an intimate friend of Ray's. Sylvia had visited Chaldon and had got to know Theo and Violet about the same time that I did.

The first of the stories in The Left Leg is dedicated to her, the second of them to me and the third to Tommy who had brought us all together.... 